\title{
Influence of gamma irradiation on the restorative interface and surface morphology of bulk fill dental composites
}

\author{
Influência da irradiação gama na interface restauradora e na morfologia de superfície de \\ compósitos dentários bulk fill \\ Influencia de la irradiación gamma en la interfaz de la restauración y en la morfología de superfície \\ de los composites dentales bulk fill
}

Received: 03/28/2021 | Reviewed: 04/08/2021 | Accept: 04/11/2021 | Published: 04/22/2021

\author{
Laís César de Vasconcelos \\ ORCID: https://orcid.org/0000-0001-6944-5196 \\ Federal University of Pernambuco, Brazil \\ E-mail: laiscv@hotmail.com \\ Gabriela Queiroz de Melo Monteiro \\ ORCID: https://orcid.org/0000-0001-5616-3405 \\ Federal University of Pernambuco, Brazil \\ E-mail: gabriela.queiroz@upe.br \\ Andréa dos Anjos Pontual \\ ORCID: https://orcid.org/0000-0003-3596-446X \\ Federal University of Pernambuco, Brazil \\ E-mail: pontual.andrea@gmail.com \\ Flávia Maria de Moraes Ramos-Perez \\ ORCID: https://orcid.org/0000-0001-9948-0769 \\ Federal University of Pernambuco, Brazil \\ E-mail: flavia.ramosperez@ufpe.br \\ Julyana de Araújo Oliveira \\ ORCID: https://orcid.org/0000-0001-6414-2612 \\ Federal University of Pernambuco, Brazil \\ E-mail: julyana.araujo@ufpe.br \\ Danyel Elias da Cruz Perez \\ ORCID: https://orcid.org/0000-0002-4591-4645 \\ Federal University of Pernambuco, Brazil \\ E-mail: danyel.perez@ufpe.br \\ Maria Luiza dos Anjos Pontual \\ ORCID: https://orcid.org/0000-0002-5900-8328 \\ Federal University of Pernambuco, Brazil \\ E-mail:mlpontual@gmail.com
}

\begin{abstract}
Objective: The purpose in this in vitro study was to evaluate the influence of gamma irradiation on the marginal integrity and surface morphology of bulk fill resin composites by Microcomputed tomography ( $\mu-\mathrm{CT})$ and Scanning Electron Microscopy (SEM). Methods: class I cavities (3 mm deep) were prepared in 60 third molars restored with the following resin composites: Filtek ${ }^{\mathrm{TM}}$ Bulk Fill (FBF), TetricEvoCeram Bulk Fill (TBF), X-tra Fil Bulk Fill (XTA) and Filtek $^{\mathrm{TM}} \mathrm{Z} 350(\mathrm{Z350})(\mathrm{n}=15)$. The samples were immersed in 50\% silver nitrate solution, scanned and subdivided according to the gamma radiation doses (Control group - no radiation, 30 and $60 \mathrm{~Gy}$ ). After irradiation, the teeth were again immersed in silver nitrate and scanned. For morphological analysis, 12 cylindrical ( $10 \mathrm{x} 2 \mathrm{~mm})$ specimens were and submitted to the studied radiation regimens $(n=4)$. Data were analyzed by the Kruskal-Wallis and Fisher LSD tests $(\alpha=0.05)$. Results: it was observed that the irradiation negatively affected the marginal integrity of samples restored with FBF $(p<0.05)$. No significant differences were observed for the other resin composites. No changes were shown in the surface morphology of bulk fill composites, despite irradiation having affected the surface morphology of the control group (Z350). It was concluded that the accumulated doses of 30 and 60 Gy negatively affected the tooth-restoration interface of FBF and at the surface morphology of Z350. Conclusions: TetricEvoCeram, and X-tra Fil Bulk Fill resin composites can be considered alternatives in the restorative treatment of patients submitted to radiotherapy of the head and neck.
\end{abstract}

Keywords: Gamma rays; Radiotherapy dosage; Dental materials; Evidence-based dentistry. 


\begin{abstract}
Resumo
Objetivo: O objetivo neste estudo in vitro foi avaliar a influencia da irradiacao gama na integridade marginal e na morfologia da superficie de compositos de resina bulk fill por tomografia microcomputadorizada ( $\mu$-CT) e microscopia eletronica de varredura (MEV). Métodos: cavidades classe I (3 mm de profundidade) foram preparadas em 60 terceiros molares restaurados com as seguintes resinas compostas: Filtek ${ }^{\mathrm{TM}}$ Bulk Fill (FBF), TetricEvoCeram Bulk Fill (TBF), X-tra Fil Bulk Fill (XTA) e Filtek ${ }^{\mathrm{TM}} \mathrm{Z} 350$ (Z350) (n = 15). As amostras foram imersas em solucao de nitrato de prata a $50 \%$, escaneadas e subdivididas de acordo com as doses de radiacao gama (Grupo controle - sem radiacao, 30 e $60 \mathrm{~Gy}$ ). Apos a irradiacao, os dentes foram novamente imersos em nitrato de prata e escaneados. Para a analise morfologica, 12 corpos de prova cilindricos $(10 \times 2 \mathrm{~mm})$ foram submetidos aos regimes de radiacao citados ( $\mathrm{n}$ =4). Os dados foram analisados pelos testes Kruskal-Wallis e Fisher LSD ( $p<0,05)$. Resultados: observou-se que a irradiacao afetou negativamente a integridade marginal das amostras restauradas com FBF $(\alpha=0,05)$. Nenhuma diferenca significativa foi observada para as outras resinas compostas. Nenhuma mudanca foi mostrada na morfologia da superficie dos compositos bulk fill, apesar da irradiacao ter afetado a morfologia da superficie do grupo de controle (Z350). Concluiu-se que as doses acumuladas de 30 e 60 Gy afetaram negativamente a interface dente-restauracao das amostras de FBF e a morfologia da superficie da Z350. Conclusoes: As resinas compostas TetricEvoCeram e X-tra Fil Bulk Fill podem ser consideradas alternativas no tratamento restaurador de pacientes submetidos a radioterapia de cabeca e pescoco.
\end{abstract}

Palavras-chave: Raios Gama; Dosagem radioterapêutica; Materiais dentários; Odontologia baseada em evidências.

\title{
Resumen
}

Objetivo: El objetivo en este estudio in vitro fue evaluar la influencia de la irradiacion gamma en la integridad marginal y la morfologia de la superficie de los compuestos de resina "bulk fill" mediante tomografia microcomputadora ( $\mu$-CT) y microscopia electronica de barrido (SEM). Metodos: Se prepararon cavidades de Clase I ( $3 \mathrm{~mm}$ de profundidad) en 60 terceros molares restaurados con las siguientes resinas compuestas: Filtek ${ }^{\mathrm{TM}}$ Bulk Fill (FBF), TetricEvoCeram Bulk Fill (TBF), X-tra Fil Bulk Fill (XTA) y Filtek ${ }^{\mathrm{TM}}$ Z350 (Z350) ( $\left.\mathrm{n}=15\right)$. Las muestras se sumergieron en una solucion de nitrato de plata al $50 \%$ se escanearon y subdividieron segun las dosis de radiacion gamma (Grupo Control - sin radiacion, 30 y 60 Gy). Despues de la irradiacion, los dientes se sumergieron nuevamente en nitrato de plata y se escanearon. Para el analisis morfologico se sometieron 12 probetas cilindricas $(10 \mathrm{x} 2 \mathrm{~mm})$ a los regimenes de radiacion antes mencionados $(n=4)$. Los datos se analizaron mediante las pruebas de KruskalWallis y Fisher LSD $(\alpha=0,05)$. Resultados: se observo que la irradiacion afecto negativamente la integridad marginal de las muestras restauradas con FBF $(\mathrm{p}<0.05)$. No se observaron diferencias significativas para las otras resinas compuestas. No se mostraron cambios en la morfologia de la superficie de los compuestos "bulk fill” , aunque la irradiacion afecto la morfologia de la superficie del grupo de control (Z350). Se concluyo que las dosis acumuladas de 30 y 60 Gy afectaron negativamente la interfaz diente-restauracion de las muestras FBF y la morfologia de la superficie de la Z350. Conclusiones: Las resinas TetricEvoCeram y X-tra Fil Bulk Fill pueden considerarse alternativas en el tratamiento restaurador de pacientes sometidos a radioterapia de cabeza y cuello.

Palabras clave: Rayos Gamma; Dosificación radioterápica; Materiales dentales; Odontología basada en la evidencia.

\section{Introduction}

Ionizing radiation at very high energies produces excitation and ionization of polymer. Released ions and free radicals may produce changes in the polymers physical and mechanical properties, enhancing the degradation processes (Amade et al., 2010; Lima et al., 2019). The analysis of irradiation influence on restorative dental materials is necessary for determining its real effect on the patients that were, or are being submitted to radiotherapy treatment, to safely and reliably support dentists' decisions at time of choosing or indicating dental materials (Troconis et al., 2017). The effect of gamma radiation on resinbased materials surface and at adhesive interface has been reported as detrimental (Naves et al., 2012).

Bulk fill resin composites seem to be a good alternative for patients who need some special attention (Ilie et al., 2013). Recently, a systematic literature review with meta-analysis evaluated the clinical effectiveness of bulk fill and conventional resin in composite restorations, and the results indicated that there is no difference between restoration with conventional and bulk resins for the type of restoration, type of tooth restored and restoration technique used (Arbildo-Vega et al., 2020). Up to date, their similar clinical performance (Adi \& Altinawi, 2020) along with easier handling and reduced clinical time favors their indication especially for patients under special needs, i.e., patients that will be submitted to radiotherapy of head and neck (Veloso et al., 2019; Furness et al., 2014). Unfortunately, the effect of radiation in these materials has not yet been evaluated. 
According to literature, the negative impact of ionizing radiation is more considerable when high doses of radiation are applied. Theoretically, this fact can affect the microstructure of resin composites and consequently its properties, such as reduction of bond and flexural strength and possible increase of microleakage (Troconis et al., 2017). Some authors suggest an increase on microhardness and decrease of the surface roughness of resin composites after irradiation, since the ionizing radiation has the same nature of the light and would cause a greater conversion of monomers in polymers (Amade et al., 2010). Nevertheless, other study showed that even low doses of ionizing radiation may decrease dentin nanohardness. This fact is related to a decrease in protein/mineral ratio, especially near dentin-enamel junction after radiotherapy (Reed et al., 2015). Unfortunately, there is still no consensus on the direct and indirect effects of ionizing radiation on the performance of resin composites and adhesive systems.

The analysis of adhesive interface should ideally be done using nondestructive methods (Troconis et al., 2017; Carrera et al., 2015). Traditional methods for microleakage studies have provided limited or even non-representative information unless various sections of the sample were analyzed (Carrera et al., 2015). Microcomputed Tomography ( $\mu$-CT) has been widely used for studying the formation of gaps and leakage in restorations and have allowed complete tridimensional reconstruction of dental restoration and surrounding tissues. These characteristics have made this method broader in scope and more quantitative (Jacker-Guhr et al., 2015; Swain \& Xue, 2009; Ersen et al., 2019).

Modifications on surface morphology of restorative materials can be evaluated using scanning electron microscopy (SEM). Through this technique, it is possible to establish different patterns of surface morphology of restorative materials after different doses of gamma irradiation that simulate protocols for radiotherapy of head and neck (Tekce et al., 2016).

Therefore, the aim in the present in vitro study was to evaluate the influence of gamma irradiation (30 and $60 \mathrm{~Gy}$ ) on the surface morphology and the adhesive interface of dental restorations using bulk fill resin composites (Filtek ${ }^{\mathrm{TM}}$ Bulk Fill, TetricEvoCeram Bulk Fill, X-tra Fil Bulk Fill). The null hypotheses tested were that radiotherapy doses of gamma irradiation do not interfere: (1) on the marginal integrity and (2) on the surface morphology of bulk fill resin composites.

\section{Methodology}

Regarding the methodological design, the study is classified as laboratory and in vitro, with an inductive approach. It is a quantitative and qualitative study (by evaluating the surface morphology of composite resins in SEM images). The research technique used in this type of study is direct observation, with data collection in the same place where the phenomena occur, in situations controlled by the researcher (Köche, 2016; Pereira et al., 2018).

\section{Sample Selection}

The study was approved by the local ethics committee (Universidade Federal de Pernambuco, protocol number 918.991). Sixty extracted caries-free third molars were used. All the samples were initially analyzed using digital radiographs. The X-ray source was the Heliodent appliance (Sirona Brasil, Sao Paulo, SP), with $70 \mathrm{kVp}$ and $7 \mathrm{~mA}$, and the digital system used was ExpressR (KaVo, USA). All samples were positioned on the $\mathrm{n} .2$ phosphorus plate $(31 \mathrm{x} 41 \mathrm{~mm}$ ) with a focus-film distance of $40 \mathrm{~cm}$ and $0.12 \mathrm{~s}$ exposure time. Carious or fractured teeth were excluded from the sample. Additionally, the selected teeth should have at least $3 \mathrm{~mm}$ between the occlusal surface (mesiobuccal cusp) and the pulp chamber.

\section{Sample preparation}

Class I occlusal cavities was prepared with a high-speed handpiece and diamond burs of regular grit under water cooling spray, coupled to a standardization device. A cylindrical bur (n.4103, KG Sorensen, Sao Paulo, SP, Brazil) was 
initially used to demarcate the preparation depth $(3 \mathrm{~mm})$. Then, a wheel-shaped bur (n.3053, KG Sorensen) was used to widen (3.8 $\mathrm{mm}$ in diameter) and regularize the cylindrical-shaped cavity. All roots were then sectioned $1 \mathrm{~mm}$ below the amelocemental junction, with the use of carborundum discs at $300 \mathrm{rpm}$ speed. Teeth were then radiographed to confirm that there was no communication with the pulp chamber. Teeth were randomly distributed into the experimental groups by draw (Table 1).

Table 1. Studied resin composites.

\begin{tabular}{ccc}
\hline Material & Composition* & $\begin{array}{c}\text { Manufacturer and } \\
\text { Batch }\end{array}$ \\
\hline
\end{tabular}

Filtek $^{\mathrm{TM}} \mathrm{Z} 350$

$\mathrm{Z} 350$

Filtek $^{\mathrm{TM}}$ Bulk Fill

FBF

Loads of silica nanoparticles (20nm) and zirconia (4-11 nm).

Ytterbium trifluoride (100nm);

76.5\% / wt.; 42.5\% / vol.; Nanoparticle.

Tetric EvoCeram Bulk Fill

TBF

\section{Bis-GMA and UDMA.}

Barium glass fillers, ytterbium trifluoride, Ba-Al

fluorosilicate glass and silica dioxide $(40-550 \mathrm{~nm})$;

79\% / wt.; 60\% / vol. (including 17\% prepolymers);

Nanohybrid

X-tra Fil

XTA
Bis-GMA, UDMA and TEGDMA

Glass beads of barium aluminum silicate and ytterbium

fluoride $(2-3 \mu \mathrm{m})$;

$86 \%$ / wt.; 70.1\% / vol.; Microhybrid.
3M ESPE, St Luis, MN, USA

Lot: 371601

3M ESPE, St Luis, MN, USA

Lot: 1521500378

Ivoclar Vivadent,

Schaan, Liechtenstein, Germany

Lot: U17294

Voco, Cuxhaven, Germany Lot: 15116628

\footnotetext{
* Bis-GMA: bisphenol-A diglycidyl ether dimethacrylate; Bis-EMA: ethoxylated bisphenol-A dimethacrylate; TEGDMA: triethyleneglycol dimethacrylate; UDMA: urethane dimethacrylate; AUDMA:aromatic urethane dimethacrylate and DDDMA: 1, 12-Dodecanediol dimethacrylate. Source: Authors.
}

For all groups, bonding procedures were done using Clearfil ${ }^{\mathrm{TM}}$ SE Bond (Kuraray Noritake Dental Inc., Okayama, Japan). The resin composites were inserted in bulk and light cured using a halogen light source (Optilight PlusTM / Gnatus, São Paulo, SP, Brazil) with $600 \mathrm{~mW} / \mathrm{cm} 2$ of irradiance mensured by a radiometer (Demetron, Kerr, Danbury, CT, USA). Samples were then immersed in a saline solution at $37^{\circ} \mathrm{C}$ for $24 \mathrm{~h}$. This immersion in saline solution aims to simulate the humidity of the oral cavity with a slightly acidic $\mathrm{pH}$, thus avoiding the syneresis of the specimens. This type of storage solution is used in most recent works of in vitro tests that evaluate the mechanical and morphological properties of dental restorative materials. Finishing and polishing were done using fine and extra fine grit diamond burs, followed by aluminum oxide 
impregnated resin finishers (Enhance / Dentsply, Rio de Janeiro, RJ, Brazil), and felt discs with diamond polishing paste (Diamond R / FGM, Joinville, SC, Brazil).

\section{Sample Irradiation}

In order to standardize image acquisition, before and after irradiation, specimens were molded with transparent acetic silicone for general or multipurpose use (Grupo Amazonas, Franca, SP, Brazil) in cylindrical polyvinyl chloride plastic holders $(4 \mathrm{~cm}$ in diameter and $4 \mathrm{~cm}$ high). Each sample was positioned inside the silicone-filled PVC tube for $24 \mathrm{~h}$ to obtain a negative imprint.

Specimens were then prepared for immersion in the tracer agent. The restoration and a $1 \mathrm{~mm}$ beyond its margins were protected with dental wax. Crowns were sealed with two layers of colorless nail varnish (Risque, Sao Paulo, SP, Brazil). After $24 \mathrm{~h}$, the restorations were immersed and kept in a 50\% silver nitrate solution (Dilecta - Farmacia de Manipulacao e Homeopatia, Joao Pessoa, PB, Brazil) for $12 \mathrm{~h}$ in the absence of light. Then, all samples were immersed into a developer solution (Carestream Dental, Sao Paulo, SP, Brazil), under fluorescent light for $6 \mathrm{~h}$. Samples were then stored in saline solution until the pre-irradiation image was obtained.

A Cobalt 60 source with gamma radiation emission (Gammacell 220 Excel, Atomic Energy of Canada, Ottawa, Canada) was used to irradiate the samples. Samples were placed in plastic polystyrene receptacles ( 34 x $20 \mathrm{~mm}$ ) containing a saline solution and then divided into 3 groups, according to the radiation doses ( $\mathrm{n}=5$ ): Control group (not irradiated), $30 \mathrm{~Gy}$ and $60 \mathrm{~Gy}$ dose of irradiation. The dose rate was $2.629 \mathrm{KGy} / \mathrm{h}$. These doses were compatible with those used in radiotherapy treatment in the region of the head, bearing in mind the different treatment protocols (Cruz et al., 2010). After irradiation, samples were re-immersed in the tracer agent and developer solution as previously described, to obtain the post-irradiation images.

\section{Sample Analysis by Computed Micro-Tomography $(\mu-C T)$}

A custom-made base was also built to hold silicone-filled PVC tubes with teeth and position the assembly on the $\mu$ CT (XT H 225 ST, Industrial CT Scanning, Nikon Metrology, Tokyo, Japan). Reference points were demarcated on the base in order to reassure the exact scanning position of the samples before and after the irradiation.

Three specimens at a time were scanned with a resolution of $18 \mu \mathrm{m}, 100 \mathrm{kV}, 100 \mu \mathrm{A}$ and $1 \mathrm{~mm}$ aluminum filter. The images were processed and reconstructed using CT Pro 3D (version 3.0.3) and VG Studio MAX (version 2.2 software). Images were then analyzed using the Image J software (version 1.51, National Institutes of Health, Bethesda, MD, USA).

The marginal integrity and presence of possible internal flaws such as fractures or bubbles within the restorations were also analyzed. Marginal defects were characterized by the presence of silver nitrate in the tooth-restoration interfaces of the cavities and visualized in the sagittal, axial and frontal planes.

The microleakage was evaluated by three experienced examiners in Computed Micro-Tomography analysis, blind as to the experimental groups. Evaluations occurred individually in a dark room, using a computer monitor (23", 1080p, Vaio, Sony Corporation Brasil). Tracer agent penetration was qualitatively evaluated in the $\mu$-CT images, by means of the following scores: 0 - no silver nitrate penetration; 1 - silver nitrate penetration up to the occlusal third of the cavity; 2- silver nitrate penetration up to the middle third of the cavity; 3 - silver nitrate penetration up to pulp third of cavity.

\section{Scanning Electron Microscopy (SEM) Assay:}

Scanning Electron Microscopy was used to analyze the surface morphology of the studied resin composites. Cylindrical specimens were made using a Teflon mold (10.0 $\mathrm{mm}$ in diameter and $2.0 \mathrm{~mm}$ thick). The mold was bulk filled with 
the resin composites, and a mylar strip and a microscope glass slide were placed on top. Digital pressure was applied to obtain a smooth and regular surface, and the specimens were light cured. Specimens were carefully removed from the mold and the excesses were removed with a scalpel blade and then immersed in saline solution $\left(37^{\circ} \mathrm{C} / 24 \mathrm{~h}\right)$. Twelve specimens were made and allocated to one of the radiation doses groups $(n=3)$. Irradiation was done with a Cobalt 60 source with gamma radiation emission (Gammacell 220 Excel) at a dose rate of $2.515 \mathrm{KGy} / \mathrm{h}$. Before SEM image acquisition, all specimens were goldsputtered under high vacuum. Samples were analyzed under scanning electron microscopy (MIRA 3, Tescan, Kohoutovice, Czech Republic) with $10 \mathrm{kVA}$, to capture images at 2000x magnification.

\section{Data Analysis}

For intra and inter-examiner evaluation, the Kappa test was performed, adopting 95\% of confidence and categorization described by Landis and Koch (14). Data were recorded in database format of the statistical package SPSS (Statistical Package for Social Sciences) for WindowsR, version 20.0, and analyzed using descriptive and inferential statistics, by applying the Kruskal-Wallis and Fisher LSD tests; and the value of the probability of 5\% was applied.

\section{Results}

\section{Computed Micro-tomography}

The intra-examiner evaluation ranged between 0.86 and 0.91 , ratifying an intensity of agreement considered "very good." Kappa inter-examiner values ranged between 0.68 and 0.91 , demonstrating "good" to "very good" intensity of agreement among the evaluators. Table 2 shows the distribution of absolute and percentage values of silver nitrate penetration using the pulp, middle and occlusal thirds as the depth parameter. It was found that, among the bulk fill resins tested, TBF did not show penetration of the tracer agent at both doses (30 and $60 \mathrm{~Gy}$ ). Only one sample of XTA allowed penetration of the tracer agent, which occurred at the dose of $60 \mathrm{~Gy}$, up to middle third. FBF presented less favorable results, with some level of tracer agent penetration in all samples, for both doses. 
Table 2. Penetration of silver nitrate in the evaluated resin composites.

\begin{tabular}{|c|c|c|c|c|}
\hline & $\begin{array}{c}\text { No } \\
\text { penetration } \\
\mathrm{n}(\%)\end{array}$ & $\begin{array}{c}\text { Occlusal } \\
\text { third } \\
\mathrm{n}(\%)\end{array}$ & $\begin{array}{c}\text { Middle } \\
\text { third } \\
\mathrm{n}(\%)\end{array}$ & $\begin{array}{l}\text { Pulp } \\
\text { third } \\
\mathrm{n}(\%)\end{array}$ \\
\hline \multicolumn{5}{|l|}{ Groups } \\
\hline \multicolumn{5}{|l|}{$\mathrm{Z} 350$} \\
\hline 0 Gy & $5(100)$ & $0(0)$ & $0(0)$ & $0(0)$ \\
\hline $30 \mathrm{~Gy}$ & $3(60)$ & $1(20)$ & $1(20)$ & $0(0)$ \\
\hline $60 \mathrm{~Gy}$ & $3(60)$ & $2(40)$ & $0(0)$ & $0(0)$ \\
\hline \multicolumn{5}{|l|}{ FBF } \\
\hline 0 Gy & $5(100)$ & $0(0)$ & $0(0)$ & $0(0)$ \\
\hline $30 \mathrm{~Gy}$ & $0(0)$ & $1(20)$ & $3(60)$ & $1(20)$ \\
\hline $60 \mathrm{~Gy}$ & $0(0)$ & $1(20)$ & $3(60)$ & $1(20)$ \\
\hline \multicolumn{5}{|l|}{$\mathrm{TBF}$} \\
\hline 0 Gy & $5(100)$ & $0(0)$ & $0(0)$ & $0(0)$ \\
\hline $30 \mathrm{~Gy}$ & $5(100)$ & $0(0)$ & $0(0)$ & $0(0)$ \\
\hline $60 \mathrm{~Gy}$ & $5(100)$ & $0(0)$ & $0(0)$ & $0(0)$ \\
\hline \multicolumn{5}{|l|}{ XBF } \\
\hline 0 Gy & $5(100)$ & $0(0)$ & $0(0)$ & $0(0)$ \\
\hline 30 Gy & $5(100)$ & $0(0)$ & $0(0)$ & $0(0)$ \\
\hline $60 \mathrm{~Gy}$ & $4(80)$ & $0(0)$ & $1(20)$ & $0(0)$ \\
\hline
\end{tabular}

Source: Authors.

Comparison of significant differences between pairs of resin compositesby irradiation doses evaluated is described in Table 3. When comparing the radiation doses among the resin composites, it was possible to find that the non-irradiated subgroup ( $0 \mathrm{~Gy}$ ) did not differ significantly among the materials tested. In both the irradiated sub-groups (30 and $60 \mathrm{~Gy}$ ), the FBF differed from other resin composites evaluated $(p<0.05)$. On the other hand, no significant difference was observed between the Z350, TBF, and XTA, resin composites between the two radiation doses.

This was the case of TBF that did not present failures at the interface in the irradiation groups, the differences described in the irradiated sub-groups of Z350 and XTA resin composites were not significant in comparison with the values of the control group, at the two irradiation doses. The FBF resin composite, however, showed marginal failures considered significant in comparison with the control group ( $\mathrm{p}<0.05$ ), however, with no differences between the doses. 
Table 3. Two by two comparison of significant differences between pairs of resins by irradiation doses.

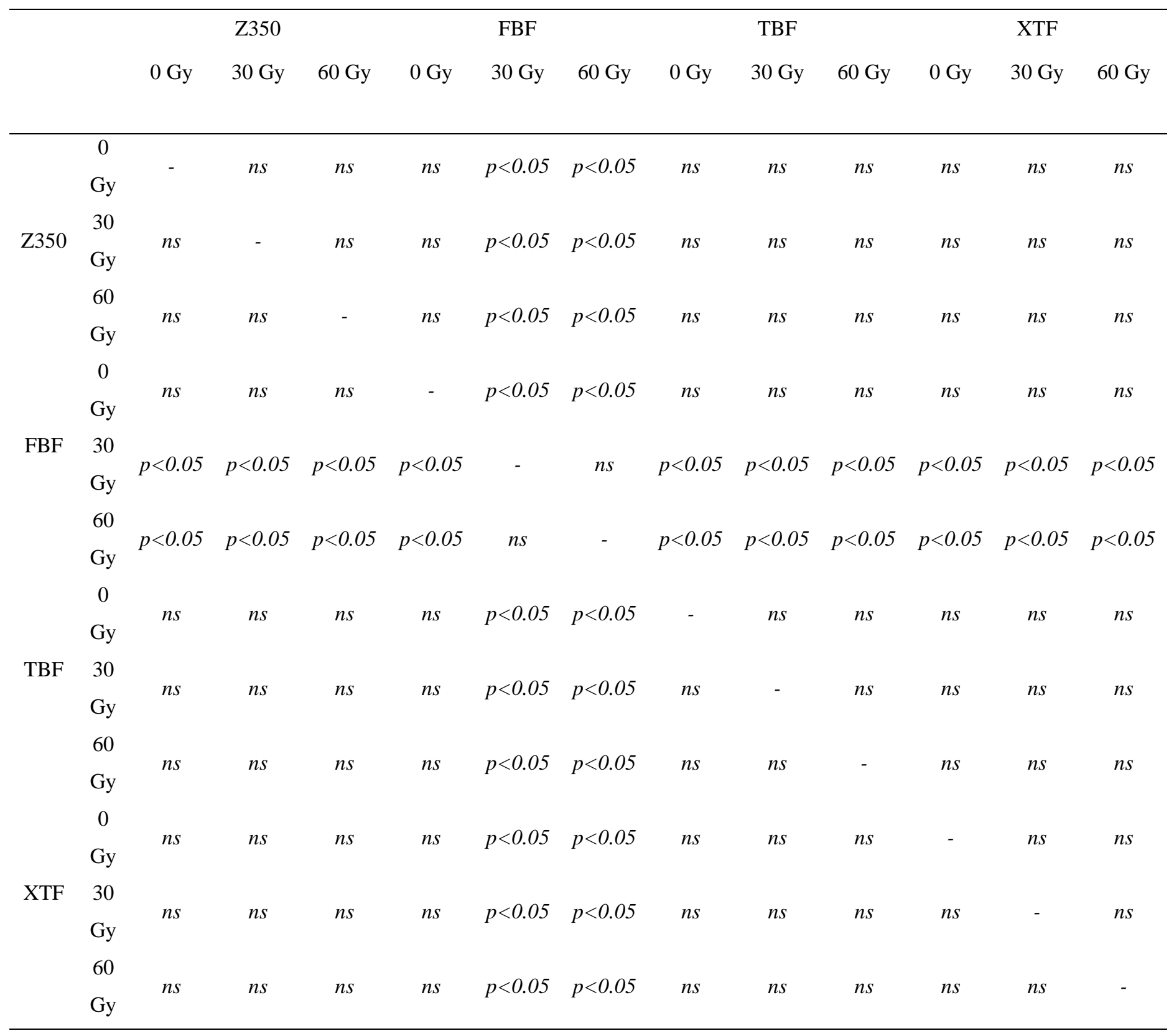

ns $=$ no statistically significant difference

$p<0.05=$ statistically significant difference by Kruskal-Wallis and Fisher LSD tests;

$\mathrm{X}=$ comparison between the same subgroup.

Source: Authors.

\section{Scanning Electron Microscopy (SEM)}

SEM images of each subgroup are shown in Figures 1-4. Z350 at 2000x magnification, in comparison with the nonirradiated group, revealed that the dose of $30 \mathrm{~Gy}$ altered surface morphology of the resin, leaving its organic matrix denser and the inorganic filler particles less apparent. The dose of $60 \mathrm{~Gy}$, for this same resin composite, resulted in a supposed formation of superficial microcavities, leaving the inorganic filler particles more detached (Figure 1). No evident and significant change was identified in the SEM images of the other resin composites evaluated (Figures 2, 3 and 4). 
Research, Society and Development, v. 10, n. 4, e53910414348, 2021

(CC BY 4.0) | ISSN 2525-3409 | DOI: http://dx.doi.org/10.33448/rsd-v10i4.14348

Figure 1. SEM images of resin Z350 (2000x). Legend: Control group (a), irradiated group $30 \mathrm{~Gy}$ (b), and irradiated group 60 Gy (c). Observe the apparent compaction of the organic matrix present in greater evidence in (b) and microcavities with most detached organic filler particles in (c) (arrows).
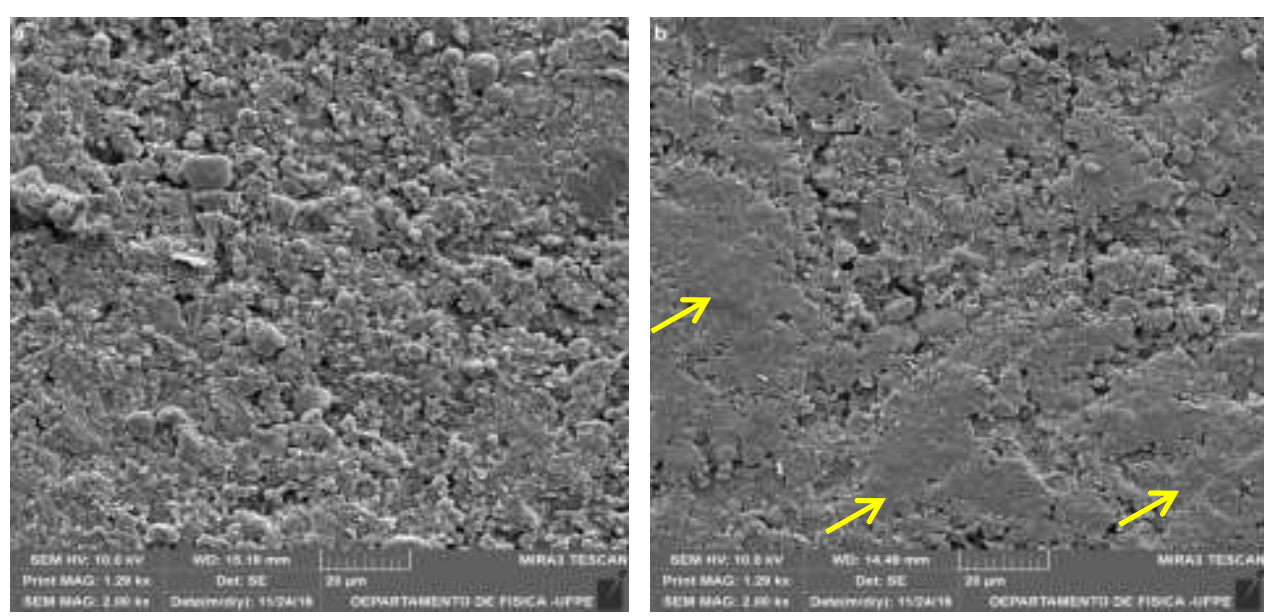

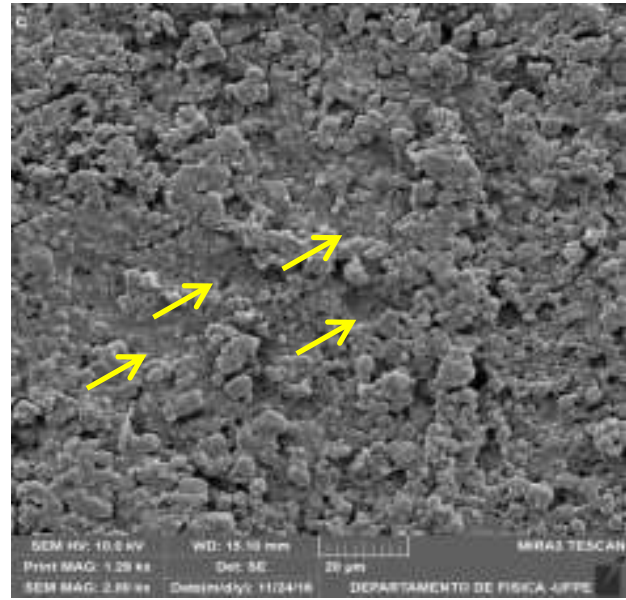

Source: Authors.

The Scanning Electron Microscopy (SEM) images of Z350 resin at 2000x magnification, in comparison with the nonirradiated group, revealed that the dose of $30 \mathrm{~Gy}$ apparently caused compaction of the resin, leaving its organic matrix denser and the inorganic filler particles less apparent. The dose of $60 \mathrm{~Gy}$, for this same resin resulted in a supposed formation of superficial microcavities, leaving the inorganic filler particles more detached.

Figure 2. SEM images of resin Filtek Bulk Fill (2000x). Legend: Control group (a), irradiated Group 30 Gy (b), and irradiated group $60 \mathrm{~Gy}$ (c).
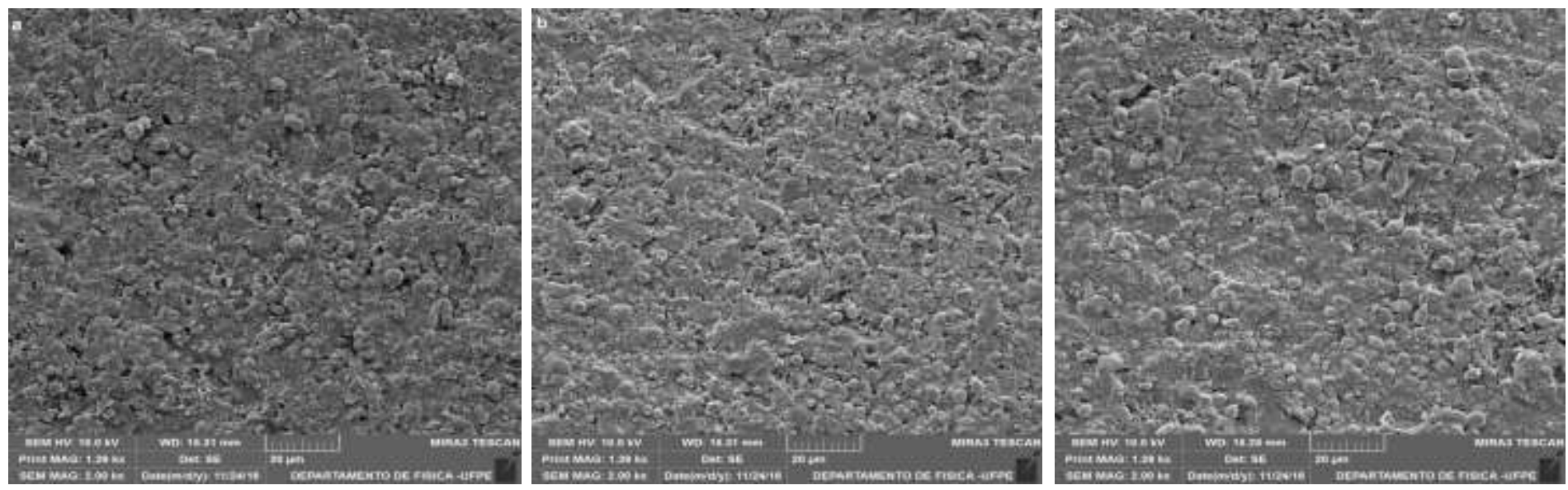

Source: Authors.

The Scanning Electron Microscopy (SEM) images of Filtek Bulk Fill clearly revealed that there was no difference in the aspect of surface morphology when comparing the control group with both irradiated groups. The superficial roughnesses appear with the same aspect in the three images, with no apparent discrepancies between them. 
Research, Society and Development, v. 10, n. 4, e53910414348, 2021

(CC BY 4.0) | ISSN 2525-3409 | DOI: http://dx.doi.org/10.33448/rsd-v10i4.14348

Figure 3. SEM images of resin Tetric EvoCeram Bulk Fill (2000x). Legend: Control group (a), irradiated group 30 Gy (b), and irradiated group $60 \mathrm{~Gy}$ (c).
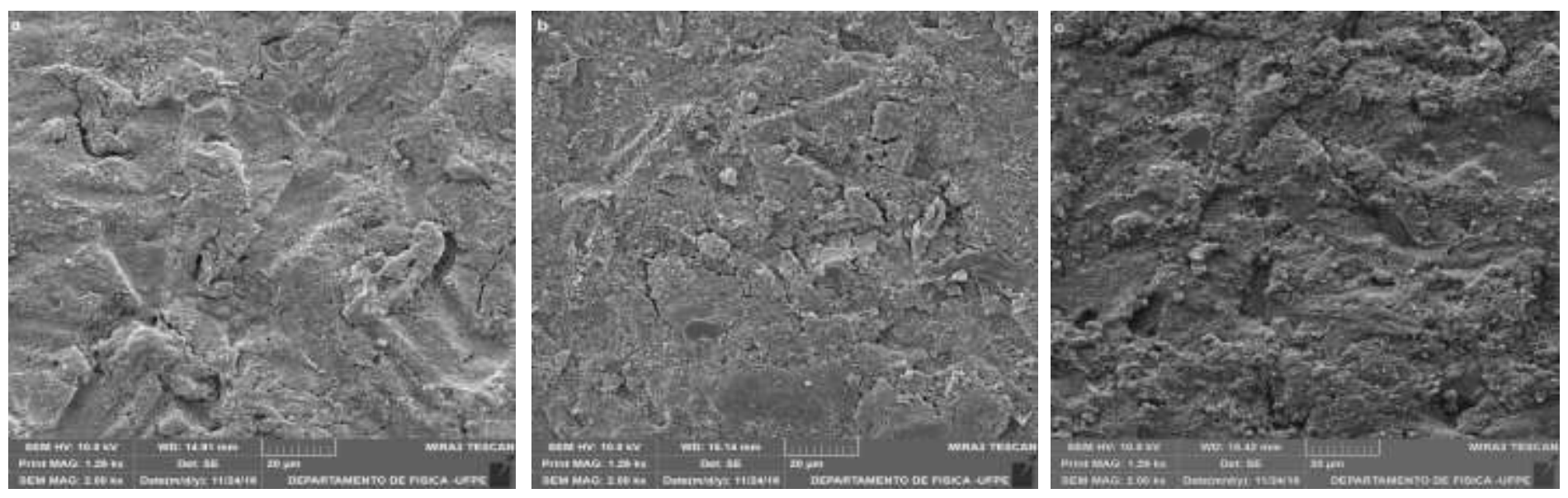

Source: Authors.

SEM images of resin Tetric EvoCeram Bulk Fill SEM images of resin Tetric EvoCeram Bulk Fill did not show differences in surface morphology between the three groups, a similar pattern is observed between the roughness present on the surface in the three images.

Figure 4. SEM images of resin X-tra Fil Bulk Fill (2000x). Legend: Control group (a), irradiated group 30 Gy (b), and irradiated group $60 \mathrm{~Gy}(\mathrm{c})$.
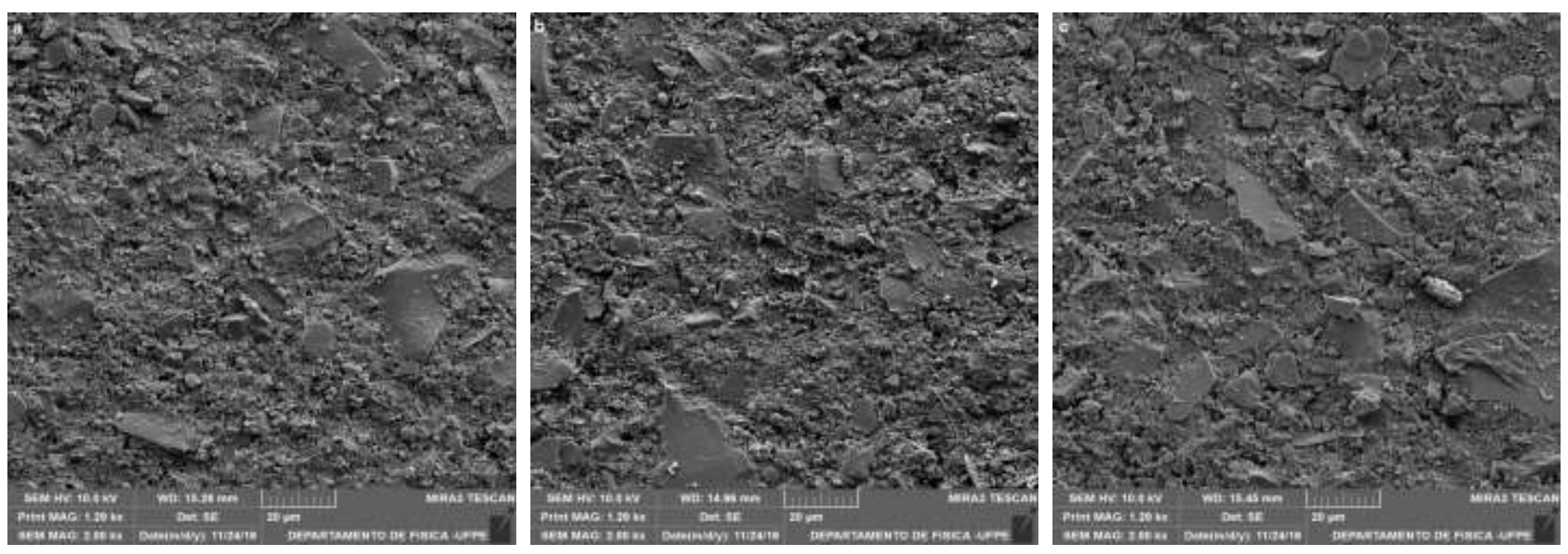

Source: Authors.

SEM images of resin X-tra Fil Bulk Fill showed a very similar surface morphology when comparing the control and irradiated groups, demonstrating that both doses do not seem to influence the appearance of changes in the surface of the resin specimens.

\section{Discussion}

As is the case with dental structures, the restorative materials are frequently vulnerable to both chemical and thermal variations that occur in the oral environment, and when we consider the therapeutic schemes for thetreatment of cancer of the 
head and neck, these materials are also susceptible to the action of radiation (Catelan et al., 2008). However, researches that determined the influence of radiation on dental restorative materials are still considered scarce, and further studies must be conducted, because there are few data in the literature from studies that have analyzed the direct correlation between irradiation and the behavior of these materials (Amade et al., 2010). Therefore, new materials and different methods of investigation are necessary, and must continually be verified.

The null hypothesis that radiotherapy doses of gamma irradiation do not interfere with the marginal integrity of resin composite restorations was rejected. Statistically significant differences were observed for the FBF group, with no differences between the radiation doses. The gamma irradiation did not interfere with the marginal integrity of conventional incrementally filled resin composite Z350 and the bulk fill resin composites TBF and XTA. Rengo at al. (2015) evaluated the silver nitrate infiltration at the adhesive interface of experimental resin composites for bulk filling in direct comparison with their precursors for conventional layering technique by computed micro-tomography. Their results did not find significant differences in among study groups. FBF irradiated samples showed silver nitrate penetration up to the pulp third of the preparation. A previous microleakage study (Orłowski et al., 2015), observed the absence of dye penetration in $86.66 \%$ of the restorations made with FBF and in $73.33 \%$ of the restorations made with TBF. However, their methodology included immersion in methylene blue dye, sample sectioning and light microscopy analysis.

The interaction between radiation and dental materials would be clinically significant if the mechanical and chemical properties of the materials are damaged. When ionizing radiation with high energy was applied directly on the dental materials, some mechanical properties of the dental materials varied in proportion to the increase in radiation dose (Troconis et al., 2017). Therefore, resin composites may become fragile after exposure to gamma radiation, particularly after high doses. A chemical study conducted by Cruz et al. conclued that aleatory changes occurred on aromaticand aliphatic bonds from organic matrix in irradiated resin composites. Probably, energy released during radiotherapycan break some chemical links from polymerized materials with negative implications in the hybrid layer, favoring the microleakage in the restorative interface (Cruz et al., 2009). However, there is a lack of data on the influence of gamma radiation on the properties of bulk fill resin composites (Troconis et al., 2017).

Structural defects strongly influence the deterioration in the mechanical properties of restorative materials. The gaps generated by irradiation are directly related to the materials filler content. It has also been reported a more significant effect of irradiation on the organic matrix of the resin composites (Campos et al., 2015). In the present study gamma irradiation negatively influenced the marginal integrity of the FBF resin that presented the lowest percentage of filler particles by volume (42.5\%) among the other resin composites tested; their filler particle content ranged from 63.3\% (Z350), 60\% including $17 \%$ prepolymers (TBF) to $70.1 \%$ (XTA).

It has been reported that the size of the filler particles of some bulk fill resin composites is increased compared to conventional incrementally filled resin composites, i.e., X-tra Fil Bulk Fill (Bucuta \& Ilie, 2000; Elmarakby, 2020). According to authors, a size increase would reduce the spaces between fillers and organic matrix, reducing the dispersion of light within the material, and favoring a better depth of polymerization of the material. Furthermore, the shape of the fillers can also benefit its translucency as observed in TBF. The surface morphology of bulk fill resin composites by SEM, demonstrated that the resin XTA had filler particles of a larger size $(1.39 \mu \mathrm{m})$ when compared to other bulk fill resin composites such as Xtra Base and Quixfill (Tekin et al., 2017). In this study, SEM analysis confirmed the presence of inorganic particles of larger size in the $\mathrm{XTA}$, and a more regular surface of the TBF at 2000x magnification.

Tekce et al. (2016) evaluated the surface morphology of FBF resin by SEM and observed at baseline ( $24 \mathrm{~h}$ in distilled water) the presence of deep pits and irregularities, in addition to filler detachment. Z350 and FBF resin composites comprise nanoagglomerates and other particles homogeneously distributed throughout the resin matrix. However, in this study, 
modifications in the surface morphology of the tested resin composites were only observed for Z350 after irradiation, not rejecting the second null hypothesis. Apparent higher density areas were demonstrated with the irradiation dose of $30 \mathrm{~Gy}$, and porous areas in with more detached inorganic fillers after the dose of $60 \mathrm{~Gy}$.

Computed micro-tomography together with silver nitrate as the contrast has been used in vitro studies to observe and quantify the presence of marginal failures, gaps, and bubbles in resin composite restorations (Carrera et al., 2015; Jacker-Guhr et al., 2015; Rengo et al., 2015). The method has the advantage of being nondestructive, broad in scope, and exposes the presence of defects at the interface satisfactorily (Carrera et al., 2015; Ersen et al., 2019). Nevertheless, Jacker-Guhr et al. (2015) affirmed that, depending on the technical characteristics of the microtomograph used, the analysis of microleakage by $\mu$-CT is impracticable, due to the time spent on generating the images (approximately $4 \mathrm{~h}$ ) and the difficulties with distinguishing the dental structures from silver nitrate, because they exhibit similar radiopacity values. In the present study, the time spent to obtain all the images of each sample was considered reasonable $(25 \mathrm{~min})$ and the tracer agent was easily differentiated at the restorative interface, shown by the excellent intra and inter-examiner agreement obtained.

When comparing the depth of polymerization, polymerization shrinkage and formation of marginal failures in bulk fill and conventional composites, Benetti et al. (2015) and Bert et al. (2020) observed that high viscosity bulk fill resin composites showed polymerization shrinkage values close to those of the conventional resin composites, resulting in smaller interface failures. Restorations using bulk fill resin composites with interfaces similar to those of Filtek Z350 resin were observed by Furness et al. (2014), Kalmowicz et al. (2015) and in the present study with the resin composites TBF and XTA. Almeida Durão et al. (2020) also found that bulk fill resin composites showed satisfactory clinical performance compared to conventional composite resin after 12 months, through a randomized clinical trial that compared FBF bulk fill resins and TBF with a conventional micro-hybrid resin composites (Z250).

On the other hand, as occurred in the studies of Tomaszewska, Kearns, and Ilie (2015), marginal failures were detected in the restorations with FBF resin. These failures could be explained according to the findings of Fronza et al. (2015), in which they observed higher polymerization shrinkage values with consequent discontinuous interfaces in these resin composites. Agreeing with Fronza et al. (2015), Ersen et al., (2019) concluded that bulk filler resin composites showed polymerization shrinkage to varying degrees, proportionally to the increase in cavity depth from 2 to $4 \mathrm{~mm}$, except for FBF. They also suggested that the application of an adhesive resin in the cavity can significantly reduce the volumetric loss and the formation of gaps. However, the appearance of another stage in the restorative process would not be interesting as it would promote a longer clinical time in the adequacy of the oral environment in patients who will be submitted to radiotherapy of the head and neck.

There are few data that analysis the direct correlation between irradiation and the behavior of restorative materials (Amade et al., 2010). Therefore, new materials and different methods of investigation are necessary and must be continually verified. Clinical studies testing the bulk fill resin composites in deep cavities and with longer follow-up periods are necessary. Considering the more straightforward clinical procedure, the use of bulk fill resin composites would favor restorative protocols for patients that will receive irradiation in the head and neck (Amade et al., 2010).

\section{Conclusion}

The gamma radiation doses ( 30 and $60 \mathrm{~Gy}$ ) negatively affected the tooth-restoration interface of the samples restored with the Filtek ${ }^{\mathrm{TM}}$ Bulk Fill resin. No changes were observed for TetricEvoCeram Bulk Fill, Xtra Fil Bulk Fill, and Filtek ${ }^{\mathrm{TM}}$ Z350. The radiation doses tested caused morphological surface alterations only for the conventional incrementally filled resin composite Filtek $^{\mathrm{TM}}$ Z350. The results of this study demonstrate that TetricEvoCeram Bulk Fill and X-tra Fil Bulk Fill resin 
composites can be considered good alternatives in the establishment of a restorative treatment protocol of patients submitted to head and neck radiotherapy.

As it is a new topic in the literature, it is suggested that further studies on the behavior of bulk fill resins after gamma irradiation should be carried out, preferably randomized and controlled clinical trials, in patients who need to undergo head and neck radiotherapy in order to to consolidate knowledge about these materials, under these conditions.

\section{List of abbreviations}

$\mu$-CT (Microcomputed tomography); SEM (Scanning Electron Microscopy); FBF (Filtek ${ }^{\mathrm{TM}}$ Bulk Fill); TBF (TetricEvoCeram Bulk Fill); XTA (X-tra Fil Bulk Fill); Z350 (Filtek ${ }^{\text {TM }}$ Z350); Gy (Gray); KVA (Kilovolt amperes); KHz (Kilohertz); KGy (Kilogray); KGy/h (Kilogray per hour); kV (Kilovoltage); kVp (Peak kilovoltage).

\section{Declarations}

\section{Ethics approval and consent to participate}

All procedures performed in this study involving human participants were following the Ethics Committee in Research with human of the Health Sciences Center, located at the Federal University of Paraiba, Brazil (protocol number 918.991) and with the 1964 Helsinki declaration and its later amendments or comparable ethical standards. Informed consent was obtained from all individual participants included in the study. This article does not contain any studies with animals performed by any of the authors.

\section{Competing interests}

The authors declare that they have no competing interests in this section.

\section{Acknowledgments}

The authors thank the Coordenacao de Aperfeicoamento de Pessoal de Nivel Superior - Brasil (CAPES) forsupporting this study. The authors also thank the X-ray Computed Tomography Laboratory of the Department of Nuclear Energy (UFPE) for their availability to use the microtomograph and for their assistance in obtaining the images.

\section{References}

Almeida Durão, M., de Andrade, A. K. M., da Silva, M. D. C. M., Montes, M. A. J. R., \& de Melo Monteiro, G. Q. (2020). Clinical Performance of Bulk-Fill Resin Composite Restorations Using the United States Public Health Service and Federation Dentaire Internationale Criteria: A 12-Month Randomized Clinical Trial. European Journal of Dentistry.

Adi, A., \& Altinawi, M. K. (2020). Marginal microleakage evaluation of class II bulk-fill composite restorations in primary molars-in vitro study. Journal of Stomatology, 73(2), 74-80.

Arbildo-Vega, H. I., Lapinska, B., Panda, S., Lamas-Lara, C., Khan, A. S., \& Lukomska-Szymanska, M. (2020). Clinical effectiveness of bulk-fill and conventional resin composite restorations: Systematic review and meta-analysis. Polymers, 12(8), 1786.

Amade, E. S., Ferreira, F. M., Novais, V. R., Correr-Sobrinho, L., \& Soares, C. J. (2010). Influência da radiação nas propriedades de diferentes materiais resinosos. Revista Odontológica do Brasil Central, 19(50).

Benetti, A. R., Havndrup-Pedersen, C., Honoré, D., Pedersen, M. K., \& Pallesen, U. (2015). Bulk fill resin composites: polymerization contraction, depth of cure, and gap formation. Operative dentistry, 40(2), 190-200.

Berti, L. S., Turssi, C. P., Amaral, F. L., Basting, R. T., Junqueira, J. L. C., Panzarella, F. K., \& França, F. M. (2020). Clinical and radiographic evaluation of high viscosity bulk-fill resin composite restorations. Am J Dent, 33(4), 213-217.

Bucuta, S., \& Ilie, N. (2014). Light transmittance and micro-mechanical properties of bulk fill vs. conventional resin based composites. Clinical oral investigations, 18(8), 1991-2000.

Campos, L. M. P., Boaro, L. C., Santos, L. K. G., Parra, D. F., \& Lugao, A. B. (2015). Influence of ionizing radiation on the mechanical properties of BisGMA/TEGDMA based experimental resin. Radiation Physics and Chemistry, 115, 30-35. 
Carrera, C. A., Lan, C., Escobar-Sanabria, D., Li, Y., Rudney, J., Aparicio, C., \& Fok, A. (2015). The use of micro-CT with image segmentation to quantify leakage in dental restorations. Dental Materials, 31(4), 382-390.

Catelan, A., Padilha, A. C., Salzedas, L. M., Coclete, G. A., \& dos Santos, P. H. (2008). Effect of radiotherapy on the radiopacity and flexural strength of a composite resin. Acta Odontol Latinoam, 21(2), 159-62.

Cruz, A. D., Almeida, S. M., Rastelli, A. N. S., Bagnato, V. S., \& Byscolo, F. N. (2009). FT-IR spectroscopy assessment of aesthetic dental materials irradiated with low-dose therapeutic ionizing radiation. Laser physics, 19(3), 461-467.

Cruz, A. D. D., Cogo, K., Bergamaschi, C. D. C., Bóscolo, F. N., Groppo, F. C., \& Almeida, S. M. D. (2010). Oral Streptococci growth on aging and nonaging esthetic restorations after radiotherapy. Brazilian dental journal, 21(4), 346-350.

Elmarakby, A. M. (2020). One Bulk Fill Composite Restorative Material: Advantages and Application Technique. EC Dental Science, 19.

Ersen, K. A., Gürbüz, Ö., \& Özcan, M. (2020). Evaluation of polymerization shrinkage of bulk-fill resin composites using microcomputed tomography. Clinical oral investigations, 24(5), 1687-1693.

Fronza, B. M., Rueggeberg, F. A., Braga, R. R., Mogilevych, B., Soares, L. E. S., Martin, A. A., \& Giannini, M. (2015). Monomer conversion, microhardness, internal marginal adaptation, and shrinkage stress of bulk fill resin composites. Dental materials, 31(12), 1542-1551.

Furness, A., Tadros, M. Y., Looney, S. W., \& Rueggeberg, F. A. (2014). Effect of bulk/incremental fill on internal gap formation of bulk fill composites. Journal of dentistry, 42(4), 439-449.

Ilie, N., Bucuta, S., \& Draenert, M. (2013). Bulk fill resin-based composites: an in vitro assessment of their mechanical performance. Operative dentistry, 38(6), 618-625.

Jacker-Guhr, S., Ibarra, G., Oppermann, L. S., Lührs, A. K., Rahman, A., \& Geurtsen, W. (2016). Evaluation of microleakage in class V composite restorations using dye penetration and micro-CT. Clinical oral investigations, 20(7), 1709-1718.

Kalmowicz, J., Phebus, J. G., Owens, B. M., Johnson, W. W., \& King, G. T. (2015). Microleakage of class I and II composite resin restorations using a sonicresin placement system. Operative dentistry, 40(6), 653-661.

Köche, J. C. (2016). Fundamentos de metodologia científica. Editora Vozes.

Landis, J. R., \& Koch, G. G. (1977). The measurement of observer agreement for categorical data. Biometrics, 159-174.

Lima, R. B. W. E., De Vasconcelos, L. C., Pontual, M. L., Meireles, S. S., Andrade, A. K. M., \& Duarte, R. M. (2019). Effect of ionizing radiation on the properties of restorative materials. Indian Journal of Dental Research, 30(3), 408.

Orłowski, M., Tarczydło, B., \& Chałas, R. (2015). Evaluation of marginal integrity of four bulk fill dental composite materials: in vitro study. The Scientific World Journal, 2015.

Naves, L. Z., Novais, V. R., Armstrong, S. R., Correr-Sobrinho, L., \& Soares, C. J. (2012). Effect of gamma radiation on bonding to human enamel and dentin. Supportive Care in Cancer, 20(11), 2873-2878.

Pereira, A. S., Shitsuka, D. M., Parreira, F. J., \& Shitsuka, R. (2018). Metodologia da pesquisa científica.

Reed, R., Xu, C., Liu, Y., Gorski, J. P., Wang, Y., \& Walker, M. P. (2015). Radiotherapy effect on nano-mechanical properties and chemical composition of enamel and dentine. Archives of oral biology, 60(5), 690-697.

Rengo, C., Spagnuolo, G., Ametrano, G., Goracci, C., Nappo, A., Rengo, S., \& Ferrari, M. (2015). Marginal leakage of bulk fill composites in Class II restorations: a microCT and digital microscope analysis. International Journal of Adhesion and Adhesives, 60, 123-129.

Swain, M. V., \& Xue, J. (2009). State of the art of Micro-CT applications in dental research. International journal of oral science, 1(4), 177-188.

Tekin, T. H., Figen, A. K., Atalı, P. Y., Filiz, B. C., \& Pişkin, M. B. (2017). Full in-vitro analyses of new-generation bulk fill dental composites cured by halogen light. Materials Science and Engineering: C, 77, 436-445.

Tekçe, N., Pala, K., Demirci, M., \& Tuncer, S. (2016). Changes in surface characteristics of two different resin composites after 1 year water storage: An SEM and AFM study. Scanning, 38(6), 694-700.

Tomaszewska, I. M., Kearns, J. O., Ilie, N., \& Fleming, G. J. (2015). Bulk fill restoratives: To cap or not to cap-That is the question?. Journal of dentistry, 43(3), 309-316.

Troconis, C. C. M., Santos-Silva, A. R., Brandao, T. B., Lopes, M. A., \& de Goes, M. F. (2017). Impact of head and neck radiotherapy on the mechanical behavior of composite resins and adhesive systems: A systematic review. Dental Materials, 33(11), 1229-1243.

Veloso, S. R. M., Lemos, C. A. A., de Moraes, S. L. D., do Egito Vasconcelos, B. C., Pellizzer, E. P., \& de Melo Monteiro, G. Q. (2019). Clinical performance of bulk fill and conventional resin composite restorations in posterior teeth: a systematic review and meta-analysis. Clinical oral investigations, 23(1), 221233. 